Костриченко В. М. [1; ORCID ID: 0000-0003-4210-6105], к.е.н., доцент,

Ковальчук B. О. ${ }^{[1 ; ~ O R C I D ~ I D: ~ 0000-0002-9762-2513], ~}$ здобувач вищої освіти другого (магістерського) рівня

${ }^{1}$ Національний університет водного господарства та природокористування, м. Рівне

\title{
ОБҐРУНТУВАННЯ КІЛЬКІСНОГО ТА ЯКІСНОГО ОЦІНЮВАННЯ АНТИКРИЗОВОЇ СТІЙКОСТІ ПІДПРИЕМСТВА
}

\begin{abstract}
Розкрита сутнісна характеристика антикризової стійкості підприємства. Проведений критичний аналіз методик оцінювання антикризової стійкості підприємства. Розроблений алгоритм комплексного обґрунтування параметрів оцінювання антикризової стійкості підприємства на засадах збалансованої системи показників. В розрізі чотирьох проєкцій (фінанси, клієнти, внутрішні бізнес-процеси, навчання та розвиток персоналу) запропонована система функціональних складових і відповідних показників антикризової стійкості підприємства. Використовуючи аналітично-оціночні процедури, виконане кількісне та якісне оцінювання рівня антикризової стійкості підприємства. За результатами розрахунків запропонована система стратегічних цілей та заходів (ініціатив) щодо підвищення антикризової стійкості підприємства. Здійснене прогнозне оцінювання зміни антикризової стійкості досліджуваного підприємства.

Ключові слова: антикризова стійкість; оцінювання антикризової стійкості підприємства; збалансована система показників; інтегральний показник; рівень антикризової стійкості; антикризова стратегія підприємства.
\end{abstract}

Постановка проблеми. Підприємство, як і будь-яка економічна система, хоч і тяжіє до рівноваги, але ніколи не буває в стані рівноваги. Воно функціонує в умовах перманентних змін зовнішнього економічного середовища і внутрішнього потенціалу, які порушують його рівноважний стан. Для підприємства як суб'єкта ринку життєвоважливою стає його здатність повертатися в стан економічної рівноваги після дії негативних кризових впливів. Відсутність своєчасної реакції підприємства і належного управлінського впливу призводять до того, що симптоми настання кризової ситуації можуть перетворитися на серйозну загрозу для подальшого його функціонування. Ці аргументи доводять необхідність проведення підприємством превентивного 
антикризового управління. Саме тому особливої актуальності набувають питання оцінювання та ідентифікації антикризової стійкості підприємства (АСП).

Аналіз останніх досліджень та публікацій. Теоретичні та прикладні аспекти більш дослідженої в науковій літературі проблеми економічної стійкості та методики їі оцінювання викладені у працях вітчизняних і зарубіжних учених, а саме: О. Ареф'євої, В. Аранчій, І.Білого, І. Бланка, О.Броіло, В. Василенка, Л.Галюк, О.Глушка, В. Іванова, М. Кизима, Д.Кондаурової, О.Клєпчевої, Т.Клочко, Л. Костирка, О. Наконечної, Н. Осокіної, О.Поліщук, І. Павлова, С. Пілецької, В. Прохорова, А. Пустуєва, О. Семененко, С. Ткаченка, О. Тридід, 3. Шевченка, В. Ячменьової та ін.

Методичні підходи щодо оцінювання антикризової стійкості описані в наукових дослідженнях В.А.Гросул, Ю.О.Джерелюк, В. О.Коюди, О.М.Костіної, В. О.Рогової, Л.В.Уривської та ін. Незважаючи на актуальність проблеми оцінювання та забезпечення АСП і накопичений певний теоретико-методичний досвід її вирішення, ряд питань залишаються дискусійними.

Метою дослідження є уточнення трактування поняття АСП та вдосконалення методичного підходу в оцінюванні АСП на засадах збалансованої системи показників (ЗСП).

Виклад основного матеріалу. В сучасній економічній науці найчастіше поняття антикризової стійкості (AC) ототожнюється 3 фінансовою стійкістю. Огляд наукових праць щодо трактування поняття «антикризова стійкість» показав, що автори, формулюючи визначення, досить часто як основу використовують такі дефініції : це здатність підприємства, це комплексна категорія, це характеристика діяльності чи стану підприємства та інше. Найбільш поширеними визначеннями АСП є такі, в яких акцент робиться на факті настання кризової ситуації та прийняття рішень щодо виходу 3 неї $[1 ; 4 ; 7 ; 8 ; 12]$.

Заслуговує на увагу трактування АС як здатності підприємства не допускати кардинального впливу кризи на його фінансовогосподарську діяльність за рахунок використання технології антикризового управління, урахування специфіки галузі та формування резервних фондів протягом фази підйому життєвого циклу підприємства [13, С. 6]. Відповідно до такого підходу АC - це здатність підприємства протистояти кризовим впливам, а в разі ж настання кризи - в максимально короткі терміни відновлювати докризовий стан; антикризова стійкість - цільова функція управління підприємством щодо запобігання кризі [11, С. 51]. 
Опираючись на існуючі наукові погляди на дану категорію, ми пропонуємо трактувати АСП як характеристику внутрішнього стану підприємства і його положення в зовнішньому економічному середовищі, при належному рівні якої підприємство здатне не допускати виникнення кризової ситуації, а у випадку їі настання може швидко відновити свою реальну вартість, маневруючи наявними ресурсами та приймаючи антикризові рішення [6, С. 211].

Оцінювання AC представляє собою комплекс дій, які дозволяють встановити рівень, динаміку і тенденції зміни показників, що характеризують результати діяльності підприємства, тобто передбачає інтерпретацію показників, які описують економічне явище. Науковці пропонують різні методики оцінювання рівня АC. Критичний аналіз існуючих методик оцінювання АСП $[1 ; 4 ; 7 ; 10]$ показав, що в науковому середовищі існують різноманітні бачення такої методики. Враховуючи, що симптоми настання кризової ситуації мають різноаспектний характер (фінансові, маркетингові, ринкові, операційні, організаційні, управлінські та інші), методичні засади оцінювання АСП мають враховувати іï сутнісну характеристику і сформульовані в [15, С. 104] методичні імперативи. На нашу думку, найкращим чином така методика може бути побудована на основі комплексного підходу та з урахуванням принципів формування збалансованої системи показників (ЗСП).

Як і традиційні системи, ЗСП містить фінансові показники як одні 3 основних критеріїв оцінки результатів діяльності підприємства, але підкреслює важливість показників нефінансового характеру, які оцінюють задоволеність покупців і акціонерів, ефективність внутрішніх бізнес-процесів, потенціал співробітників 3 метою забезпечення довгострокового фінансового успіху підприємства.

ЗСП призначена дати відповіді на чотири найважливіших для підприємства запитання: як оцінюють підприємство акціонери (фінансовий аспект); як оцінюють підприємство клієнти (аспект клієнта); які бізнес-процеси можуть забезпечити підприємству виключні конкурентні переваги (внутрішньогосподарський аспект); яким чином можна досягнути подальшого поліпшення становища підприємства (аспект інновацій і навчання).

Запропонований нами алгоритм оцінювання АСП [5, С. 60-61] враховує актуальні методичні напрацювання i дозволяє продемонструвати особливості методики комплексного оцінювання AC, яка передбачає використання аналітичних та оціночних процедур (рисунок). 


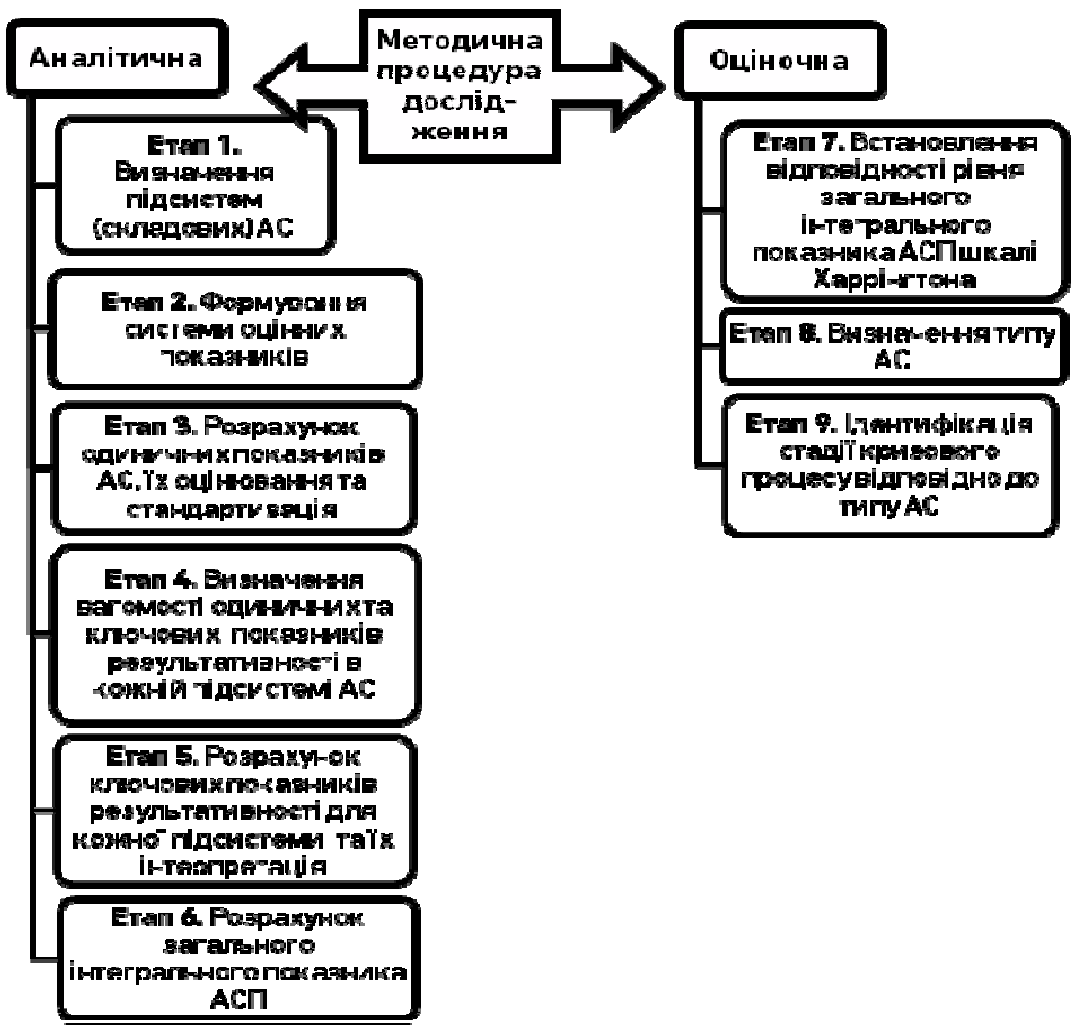

Рисунок. Алгоритм комплексного оцінювання антикризової стійкості підприємства

Джерело: власна розробка авторів

Аналітичні процедури передбачають використання такого економічного інструментарію, який дозволяє визначити рівень АСП. Оціночні процедури забезпечують встановлення відповідності рівня АСП, розрахованого на основі комплексної оцінки, певному типу AC i стадії кризового процесу.

В даному алгоритмі методична процедура дослідження має включати такі етапи:

Етап 1. Запропонований нами склад підсистем економічної стійкості опирається на сучасні економічні тенденції та передбачає виокремлення складових, від яких залежить стійке функціонування і розвиток підприємства. АС включає фінансову, маркетингову, виробничу, інвестиційно-інноваційну, управлінсько-інформаційну, кадрову складову.

Етап 2. Серед значної кількості фінансових коефіцієнтів увага має бути зосереджена на показниках фінансової підсистеми, які демонструють ділову активність, ліквідність, платоспроможність та 
рентабельність підприємства. Показники маркетингової стійкості будуть зорієнтовані на реалізацію продукції та результативність збутових витрат. Показники виробничої стійкості мають показати якість продукції та рівень використання ресурсів суб'єкта підприємництва. Серед показників інвестиційної стійкості обирають ті, що характеризують фінансову підтримку виробничого процесу та інших видів діяльності і рентабельність вкладень; а для інноваційної стійкості - матеріально-технічну та інтелектуальну компоненту. Показники управлінсько-інформаційної та кадрової підсистеми можуть бути якісними (освіта, кваліфікація, досвід), що потребує переведення їх за допомогою коригуючих коефіцієнтів у кількісний вимір, а також мають бути показники рівня управління кадрами.

Етап 3. Аналітичне опрацювання розрахованих одиничних показників AC 3 використанням карт стійкості дозволяє ідентифікувати рівень стійкості в межах окремої підсистеми. Оскільки одиничні показники АС виражені в абсолютних і відносних величинах, а також мають різні одиниці виміру, то для забезпечення співставності характеристик, що входять до складу агрегованих показників, необхідно здійснити процедуру стандартизації.

Етап 4. Для визначення ваги окремого одиничного показника можуть бути використані спеціальні кваліметрії (наприклад, експертна, ймовірнісно-статистична, індексна, таксономічна кваліметрія та ін.). Ключові показники результативності мають бути збалансовані у відповідності із показниками вагомості, які визначаються експертним методом із залученням практиків та науковців. Ступінь узгодженості експертів оцінюється за допомогою коефіцієнта конкордації Кендала.

Визначати вагові коефіцієнти можна також, скориставшись правилом Фішберна, яке дає можливість визначити рівень значущості показників на основі їхнього ранжування.

Етап 5. Агреговані (ключові) показники результативності розраховуються для кожної із виокремлених складових АС на основі стандартизованих одиничних показників, які збалансовані у відповідності з показниками вагомості.

Етап 6. В розрахунку загального інтегрального показника АСП враховується рівень впливу і-го ключового показника результативності підсистеми АС та його вагомість.

Етап 7. Інтегральний показник АСП згідно з п'ятибальною шкалою Харрінгтона [14] може відповідати дуже високому, високому, середньому, низькому або дуже низькому рівню.

Етап 8. Певному рівню загального інтегрального показника АСП 
відповідає один із типів АС. Характеристика абсолютної стійкості, достатньої стійкості, нестійкого економічного стану, низької стійкості, катастрофічної стійкості містить сукупність певних ознак у відповідних підсистемах АС. Так, абсолютна АС визнається, якщо підприємство має високий рівень фінансово-економічного стану, для якого характерним $\epsilon$ таке: стан фінансових ресурсів забезпечує безперервний процес виробництва та реалізації, витрати 3 його розширення та оновлення; стабільність виробничого циклу та налагодженість його ресурсного забезпечення; високий рівень ділової активності, надійність економічних зв'язків і велика частка ринку; здійснюється реальне інвестування, впровадження нових технологій і способів організації виробництва, випуску нових видів продукції; забезпечується підвищення кваліфікації трудових ресурсів, їх залучення до організаційно-управлінських процесів. Типологія АС корелює із рівнем показника АСП.

Етап 9. Встановлюється відповідність рівня показника АСП певній стадії кризового процесу: кризове явище, кризова ситуація, передкризовий стан, кризовий стан, криза.

Апробація запропонованого алгоритму оцінювання АСП проведена на базі реальних даних державного підприємства «Бурштин України», яке засноване на державній власності. Предметом діяльності підприємства $є$ : видобуток, переробка, обробка, використання та застосування дорогоцінних металів, каміння органогенного утворення, напівдорогоцінного каміння для виробничих, інвестиційних чи комерційних потреб; виробництво виробів широкого вжитку та виробничо-технічного призначення, використання дорогоцінних металів, дорогоцінного каміння, дорогоцінного каміння органогенного утворення, напівдорогоцінного та декоративного каміння та реалізація на внутрішньому та зовнішніх ринках; здійснення оптової та роздрібної торгівлі, у тому числі дорогоцінними металами, дорогоцінним камінням, дорогоцінним камінням органогенного утворення, напівдорогоцінним та декоративним камінням, продуктами їх переробки тощо.

На діяльність підприємства істотний вплив чинить надмірна поширеність тіньового видобутку бурштину, що значно ускладнює умови та результати роботи підприємства, в тому числі ті, що визначають можливості мотивування персоналу.

Діяльність підприємства реалізується у трьох напрямках: прикраси, сувеніри жіночого та чоловічого асортименту; вироби з бурштину в сріблі; виробництво картин, ікон, портретів з бурштину, які виготовляються за унікальною та єдиною в світі технологією, розробленою майстрами ДП «Бурштин України». Підприємство 
виробляє понад 500 видів ювелірних прикрас з бурштину та дорогоцінних металів (намиста, браслети, кулони, брошки, сережки, перстні, підвіски, кольє тощо) [9]. Такого асортименту не пропонує жоден 3 конкурентів підприємства навіть серед тих, хто спеціалізується виключно на торгівлі готовою продукцією.

Підприємство пропонує величезний вибір оригінальної продукції та створює вироби під індивідуальні замовлення. Унікальність виробів полягає у їх цілісності, без використання клею, а також вироби можуть містити різні органічні залишки, наприклад, хвіст ящірки чи дрібну мураху. Якщо розглядати виріб під мікроскопом, то мураха, яка застигла у бурштині (скам'янілій смолі хвойних дерев) мільйони років тому, виглядає зовсім не ушкодженою. Такі екземпляри дуже ціняться та коштують набагато більше.

Підприємство намагається втримувати конкурентну позицію на ринку за рахунок забезпечення високої якості продукції та збереження кадрового складу, особливо в частині працівників 3 високою кваліфікацією, що в умовах економічної кризи та зменшення попиту на товари, які належать до групи селективного або навіть ексклюзивного попиту, не може не позначитись на економічних результатах діяльності підприємства.

Аналіз основних економічних показників діяльності ДП «Бурштин України» за 2014-2018 роки показав, що лише у 2015 році обсяг реалізованої продукції перевищував обсяг їі виробництва. У решту років обсяг реалізованої продукції був меншим, ніж обсяг виготовленої продукції, про що свідчить зростання запасів готової продукції на складах підприємства. Загалом 32016 року спостерігається тенденція до спадання як обсягів виробництва, так і обсягів реалізації. У 2018 році підприємство не мало чистого прибутку і його діяльність була збитковою.

В процесі дослідження було проведене кількісне оцінювання антикризової стійкості підприємства за інтегральним показником. Для цього в розрізі чотирьох проєкцій збалансованої системи показників, а саме: фінанси, клієнти, внутрішні бізнес-процеси, навчання та розвиток персоналу, були визначені функціональні складові і система відповідних показників загальної АС ДП «Бурштин України». Наступні аналітичні операції передбачають визначення коефіцієнтів вагомості згрупованих показників в кожній групі стійкості, а також визначення їх збалансованих значень, що були використані при розрахунку величини інтегрального показника. Результати проведених розрахунків наведено в табл. 1. 
Стандартизовані та збалансовані показники антикризової стійкості ДП «Бурштин України»

\begin{tabular}{|c|c|c|c|c|c|c|c|c|c|c|c|c|}
\hline \multirow{2}{*}{$\begin{array}{l}\text { № } \\
3 / \Pi\end{array}$} & \multirow{2}{*}{$\begin{array}{l}\text { Показники складових } \\
\text { антикризової стійкості }\end{array}$} & \multirow{2}{*}{$\begin{array}{c}\text { Вагомість } \\
\text { показників }\end{array}$} & \multicolumn{5}{|c|}{$\begin{array}{c}\text { Стандартизовані показники ДП } \\
\text { «Бурштин України» за роки }\end{array}$} & \multicolumn{5}{|c|}{$\begin{array}{l}\text { Збалансовані показники ДП } \\
\text { «Бурштин України» за роки }\end{array}$} \\
\hline & & & 2014 & 2015 & 2016 & 2017 & 2018 & 2014 & 2015 & 2016 & 2017 & 2018 \\
\hline \multicolumn{13}{|c|}{ Фінанси } \\
\hline 1 & Ліквідності & 0,2 & 1,000 & 0,968 & 0,927 & 0,931 & 0,783 & 0,200 & 0,194 & 0,185 & 0,186 & 0,157 \\
\hline 2 & Фінансової стійкості & 0,25 & 1,000 & 0,963 & 0,927 & 0,924 & 0,882 & 0,250 & 0,241 & 0,232 & 0,231 & 0,220 \\
\hline 3 & Ділової активності & 0,15 & 0,793 & 1,000 & 0,624 & 0,592 & 0,450 & 0,119 & 0,150 & 0,094 & 0,089 & 0,067 \\
\hline 4 & Майнового стану & 0,2 & 0,828 & 0,849 & 0,885 & 0,946 & 1,000 & 0,166 & 0,170 & 0,177 & 0,189 & 0,200 \\
\hline 5 & Рентабельності & 0,2 & 0,465 & 1,000 & 0,020 & $-0,002$ & $-0,625$ & 0,093 & 0,200 & 0,004 & 0,000 & $-0,125$ \\
\hline $\begin{array}{l}\text { Агре } \\
\text { фіна }\end{array}$ & $\begin{array}{l}\text { гований показник } \\
\text { нсової стійкості }\end{array}$ & 1 & & & & & & 0,828 & 0,954 & 0,692 & 0,695 & 0,520 \\
\hline \multicolumn{13}{|c|}{ Клієнти } \\
\hline 6 & $\begin{array}{l}\text { Коефіцієнт збереження } \\
\text { клієнтської бази }\end{array}$ & 0,2 & 0,081 & 0,015 & 0,363 & 0,072 & 1,000 & 0,016 & 0,003 & 0,073 & 0,014 & 0,200 \\
\hline 7 & $\begin{array}{l}\text { Коефіцієнт розширення } \\
\text { клієнтської бази }\end{array}$ & 0,35 & 0,347 & 1,000 & 0,097 & 0,020 & 0,000 & 0,122 & 0,350 & 0,034 & 0,007 & 0,000 \\
\hline 8 & $\begin{array}{l}\text { Коефіцієнт, що } \\
\text { характеризує } \\
\text { прибутковість клієнта } \\
\end{array}$ & 0,2 & 0,506 & 1,000 & 0,042 & 0,002 & 0,000 & 0,101 & 0,200 & 0,008 & 0,000 & 0,000 \\
\hline 9 & $\begin{array}{l}\text { Частка підприємства на } \\
\text { ринку, \% }\end{array}$ & 0,25 & 0,674 & 1,000 & 0,881 & 0,036 & 0,020 & 0,168 & 0,250 & 0,220 & 0,009 & 0,005 \\
\hline $\begin{array}{l}\text { Агре } \\
\text { кліє }\end{array}$ & $\begin{array}{l}\text { гований показник стійкості } \\
\text { нтів }\end{array}$ & 1 & & & & & & 0,407 & 0,803 & 0,335 & 0,031 & 0,205 \\
\hline \multicolumn{13}{|c|}{ Внутрішні бізнес-процеси } \\
\hline 10 & $\begin{array}{l}\text { Питома вага своєчасно } \\
\text { доставлених замовлень } \\
\text { постачальниками }\end{array}$ & 0,2 & 0,998 & 1,000 & 0,999 & 1,000 & 0,996 & 0,200 & 0,200 & 0,200 & 0,200 & 0,199 \\
\hline
\end{tabular}


продовження табл. 1

\begin{tabular}{|c|c|c|c|c|c|c|c|c|c|c|c|c|}
\hline 11 & $\begin{array}{l}\text { Рентабельність реалізованої } \\
\text { продукції }\end{array}$ & 0,3 & 0,506 & 1,000 & 0,042 & 0,002 & $\begin{array}{c}- \\
1,538 \\
\end{array}$ & 0,152 & 0,300 & 0,013 & 0,000 & $-0,461$ \\
\hline 12 & $\begin{array}{l}\text { Iндекс прибутковості } \\
\text { впроваджених } \\
\text { інвестиційно-інноваційних } \\
\text { проєктів }\end{array}$ & 0,2 & 0,000 & 0,000 & 0,000 & 0,000 & 0,000 & 0 & 0 & 0 & 0 & 0 \\
\hline 13 & $\begin{array}{l}\text { Питома вага доходу, } \\
\text { отриманого від } \\
\text { інвестиційно-інноваційних } \\
\text { проєктів }\end{array}$ & 0,3 & 0,090 & 1,000 & 0,796 & 0,209 & 0,000 & 0 & 0,300 & 0,239 & 0,063 & 0 \\
\hline & $\begin{array}{l}\text { гований показник стійкості } \\
\text { рішніх бізнес-процесів }\end{array}$ & 1 & & & & & & 0,352 & 0,800 & 0,451 & 0,263 & $-0,262$ \\
\hline \multicolumn{13}{|c|}{ Навчання та розвиток персоналу } \\
\hline 14 & $\begin{array}{l}\text { Коефіцієнт забезпеченості } \\
\text { сучасними програмами }\end{array}$ & 0,2 & 0,519 & 0,942 & 1,000 & 0,938 & 0,796 & 0,104 & 0,188 & 0,200 & 0,188 & 0,159 \\
\hline 15 & Коефіцієнт ініціативи & 0,15 & 0,720 & 0,698 & 1,000 & 0,289 & 0,255 & 0,108 & 0,105 & 0,150 & 0,043 & 0,038 \\
\hline 16 & $\begin{array}{l}\text { Коефіцієнт корпоративної } \\
\text { культури }\end{array}$ & 0,15 & 1,000 & 0,908 & 0,595 & 0,269 & 0,253 & 0,150 & 0,136 & 0,089 & 0,040 & 0,038 \\
\hline 17 & $\begin{array}{l}\text { Коефіцієнт стимулювання } \\
\text { роботи в команді }\end{array}$ & 0,1 & 0,857 & 0,533 & 0,560 & 0,800 & 1,000 & 0,086 & 0,053 & 0,056 & 0,080 & 0,100 \\
\hline 18 & $\begin{array}{l}\text { Коефіцієнт стабільності } \\
\text { кадрів }\end{array}$ & 0,2 & 0,810 & 1,000 & 0,484 & 0,362 & 0,875 & 0,162 & 0,200 & 0,097 & 0,072 & 0,175 \\
\hline 19 & $\begin{array}{l}\text { Коефіцієнт прибутковості на } \\
\text { одного працюючого }\end{array}$ & 0,2 & 0,300 & 1,000 & 0,034 & 0,001 & $-1,174$ & 0,060 & 0,200 & 0,007 & 0,000 & $-0,235$ \\
\hline \multicolumn{2}{|c|}{$\begin{array}{l}\text { Агрегований показник стійкості } \\
\text { навчання та розвитку персоналу }\end{array}$} & 1 & & & & & & 0,670 & 0,882 & 0,599 & 0,424 & 0,275 \\
\hline
\end{tabular}

Джерело: власна розробка авторів 
Аналіз отриманих результатів дозволяє стверджувати, що агрегований показник фінансової стійкості підприємства знизився за 2014-2018 роки з 0,828 до 0,520, що зумовлене суттєвим зниження рентабельності і збитковістю діяльності в останні роки. Агрегований показник стійкості клієнтів показав також суттєве погіршення показників маркетингової складової з 0,407 до 0,205. Агрегований показник стійкості внутрішніх бізнес-процесів знизився з 0,352 до 0,262 через збитковість і відсутність інвестицій. Агрегований показник стійкості навчання та розвитку персоналу також показав низхідну тенденцію від 0,670 до 0,275 через зниження коефіцієнтів ініціативи та корпоративної культури, а також низьку прибутковість в розрахунку на одного працівника.

Негативні тенденції зміни кожної із функціональних складових АСП знайшли своє відображення в динаміці інтегрального показника за 2014-2018 роки (табл. 2).

Таблиця 2

Інтегральний показник антикризової стійкості

ДП «Бурштин України» в динаміці за 2014-2018 роки

\begin{tabular}{|l|l|c|l|l|l|l|l|}
\hline \multirow{2}{*}{$\begin{array}{l}\text { № } \\
\text { 3/п }\end{array}$} & $\begin{array}{l}\text { Показники антикризової } \\
\text { стійкості }\end{array}$ & Вагомість & \multicolumn{5}{|c|}{ поки } \\
\cline { 5 - 8 } 1. & Фінансова стійкість & 0,3 & 0,828 & 0,954 & 0,692 & 0,695 & 0,520 \\
\hline 2. & Клієнти & 0,25 & 0,407 & 0,803 & 0,335 & 0,031 & 0,205 \\
\hline 3. & $\begin{array}{l}\text { Внутрішні бізнес- } \\
\text { процеси }\end{array}$ & 0,2 & 0,352 & 0,800 & 0,451 & 0,263 & $-0,262$ \\
\hline 4. & $\begin{array}{l}\text { Навчання та розвиток } \\
\text { персоналу }\end{array}$ & 0,25 & 0,670 & 0,882 & 0,599 & 0,424 & 0,275 \\
\hline $\begin{array}{l}\text { Інтегральний показник } \\
\text { антикризової стійкості }\end{array}$ & 1 & 0,588 & 0,868 & 0,531 & 0,375 & 0,224 \\
\hline
\end{tabular}

Джерело: власна розробка авторів

Розрахунки показали, що для підприємства найбільш успішним був 2015 рік, коли цей показник становив 0,868. Усі наступні роки інтегральний показник АСП неухильно знижувався аж до 0,224 у 2018 році.

Процес оцінювання не завершується розрахунком загального інтегрального показника АСП. Далі, використовуючи шкалу Харрінгтона, визначається тип АС і встановлюється відповідність рівня показника АСП певній стадії кризового процесу (табл. 3). 
Відповідність типу і рівня загального інтегрального показника АСП стадії кризового процесу за шкалою Харрінгтона

\begin{tabular}{|l|c|c|c|}
\hline \multirow{2}{*}{\multicolumn{1}{|c|}{ Тип AC }} & \multicolumn{3}{|c|}{ Відповідність типу АС стадії кризового процесу } \\
\cline { 2 - 4 } & $\begin{array}{c}\text { Діапазон } \\
\text { значень }\end{array}$ & $\begin{array}{c}\text { Рівень } \\
\text { показника АСП }\end{array}$ & $\begin{array}{c}\text { Стадія } \\
\text { кризового } \\
\text { процесу }\end{array}$ \\
\hline Абсолютна AC & $1,00-0,80$ & Дуже високий & кризове явище \\
\hline Достатня АC & $0,80-0,63$ & Високий & $\begin{array}{c}\text { кризова } \\
\text { ситуація }\end{array}$ \\
\hline $\begin{array}{l}\text { Нестійкий економічний } \\
\text { стан }\end{array}$ & $0,63-0,37$ & Середній & $\begin{array}{c}\text { передкризовий } \\
\text { стан }\end{array}$ \\
\hline Низька АС & $0,37-0,20$ & Низький & кризовий стан \\
\hline $\begin{array}{l}\text { Катастрофічна АС } \\
\text { (нестійкість) }\end{array}$ & $0,20-0,00$ & Дуже низький & криза \\
\hline
\end{tabular}

Джерело: власна розробка авторів на основі [5; 14]

За результатами розрахунків було побудовано карту оцінювання АС ДП «Бурштин України» за 2014-2018 роки (табл. 4). Така карта дозволяє візуалізувати в динаміці зміну рівня стійкого розвитку підприємства в розрізі чотирьох проєкцій збалансованої системи показників.

Як показали розрахунки, за досліджуваний період практично в кожній із проєкцій відбулося зниження АС. Так, у 2018 році інтегральний показник АС проєкції «Фінанси» свідчив про нестійкий економічний стан ДП «Бурштин України». Інтегральні показники АC проєкцій «Клієнти» і «Навчання та розвиток персоналу» показали низьку АС досліджуваного підприємства. Найбільш проблемною для підприємства була проєкція «Внутрішні бізнес-процеси», інтегральний показник якої вказував на катастрофічну АСП.

Отримані результати свідчать про загрозу зниження реальної вартості ДП «Бурштин України» і проблематичність швидкого ії відновлення.

Запропонована ідентифікація АСП створює підґрунтя для прийняття підприємством ефективних господарських рішень. Виходячи з отриманих результатів розрахунку окремих показників ЗСП, для ДП «Бурштин України» можна запропонувати відповідну збалансовану систему стратегічних цілей та рішень, реалізація яких має безпосередній вплив на рівень АСП. Так, для фінансової проєкції ціль «прибутковий ріст бізнесу» може бути забезпечена реалізацією програми росту; для проєкції клієнтів ціль «розширення і підтримка клієнтської бази» - реалізацією програми підвищення лояльності клієнтів; для проєкції внутрішніх бізнес-процесів ціль «розширення виробничих і фінансових можливостей» - реалізацією корпоративної 
Таблиця 4

Карта оцінювання антикризової стійкості ДП «Бурштин України» за 2014-2018 рр.

\begin{tabular}{|c|c|c|c|c|c|c|c|c|c|c|c|c|c|c|c|c|c|c|c|c|}
\hline \multirow{2}{*}{$\begin{array}{c}\text { Рівень } \\
\text { стійкого } \\
\text { розвитку } \\
\text { підприємства }\end{array}$} & \multicolumn{5}{|c|}{ Фінанси } & \multicolumn{5}{|c|}{ Клієнти } & \multicolumn{5}{|c|}{$\begin{array}{c}\text { Внутрішні бізнес- } \\
\text { процеси }\end{array}$} & \multicolumn{5}{|c|}{$\begin{array}{c}\text { Навчання та розвиток } \\
\text { персоналу }\end{array}$} \\
\hline & ¿ & $\stackrel{\text { L }}{\stackrel{\sim}{\sim}}$ & 임 & ¿ & $\stackrel{\infty}{\infty}$ & $\stackrel{+}{\stackrel{N}{N}}$ & $\stackrel{\text { L }}{\frac{1}{2}}$ & 赵 & ¿ & $\stackrel{\infty}{\infty}$ & $\stackrel{+}{\text { N }}$ & 冓 & 임 & 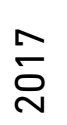 & $\frac{\infty}{\infty}$ & $\stackrel{ \pm}{\stackrel{N}{2}}$ & $\frac{10}{\infty}$ & 요 & ¿ & $\stackrel{\infty}{\infty}$ \\
\hline $\begin{array}{l}\text { Абсолютна АС } \\
(0,8-1,0)\end{array}$ & $\underset{\substack{\infty \\
\infty \\
0 \\
0}}{0}$ & $\begin{array}{l}\text { Lे } \\
\text { 号 } \\
0\end{array}$ & & & & & 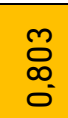 & & & & & $\begin{array}{l}8 \\
\substack{8 \\
\infty \\
0 \\
0}\end{array}$ & & & & & $\begin{array}{c}\text { D } \\
\text { o. } \\
0 \\
0\end{array}$ & & & \\
\hline $\begin{array}{l}\text { Достатня AC } \\
(0,63-0,80)\end{array}$ & & & $\begin{array}{l}N \\
\alpha \\
0 \\
0\end{array}$ & $\begin{array}{l}\text { L } \\
\text { 各 } \\
0 \\
0\end{array}$ & & & & & & & & & & & & 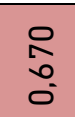 & & & & \\
\hline $\begin{array}{l}\text { Нестійка AC } \\
(0,37-0,63)\end{array}$ & & & & & ్ㅗㅁ & $\begin{array}{l}\hat{o} \\
\text { ơ }\end{array}$ & & & & & & & 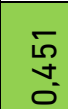 & & & & & 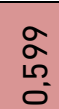 & \begin{tabular}{c}
\multirow{J}{*}{} \\
ज.
\end{tabular} & \\
\hline $\begin{array}{l}\text { Низька АC } \\
(0,20-0,37)\end{array}$ & & & & & & & & $\stackrel{\stackrel{L}{m}}{m}$ & & $\stackrel{\substack{n \\
\hdashline}}{\sim}$ & 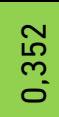 & & & 芯 & & & & & & 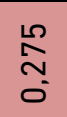 \\
\hline $\begin{array}{l}\text { Катастрофічна } \\
\text { АС } \\
(0-0,20)\end{array}$ & & & & & & & & & $\begin{array}{l}\bar{m} \\
0 \\
0\end{array}$ & & & & & & 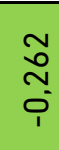 & & & & & \\
\hline
\end{tabular}


програми розвитку виробництва; для проєкції навчання та розвитку персоналу ціль «створення ефективної команди» - реалізацією програми формування системи комунікацій.

Проведене економічне обґрунтування рішень, запропонованих для ДП «Бурштин України», дозволило оцінити прогнозне значення рівня його антикризової стійкості. Як показали розрахунки, підприємство отримає можливість підвищити свою АС з 0,224 до 0,457, тобто вийти із зони низької АС. Для підприємства це буде означати, що воно зможе перейти від кризового стану у передкризовий стан, тим самим дещо покращити своє фінансове становище і ринкові позиції.

Висновки. Запропонований в дослідженні алгоритм комплексного оцінювання АСП представлений системою аналітичних та оціночних процедур. Він $є$ адаптованим до сучасних методичних імперативів та враховує комунікації рівнів АС та стадій кризового процесу. Оцінювання АСП проводиться за ключовими показниками результативності для кожної із підсистем стійкості та інтегральним показником АСП. Зниження АС від абсолютної стійкості до катастрофічної стійкості (фактично нестійкого стану) сигналізує про розгортання кризового процесу на підприємстві від кризового явища до кризи. Наявність інформації про рівень АСП та його динаміку дозволяє, використовуючи практичний інструментарій превентивного антикризового управління, розробити та впровадити адекватні господарські рішення, направлені на досягнення АСП.

Для забезпечення стійкого розвитку та функціонування підприємства в довгостроковій перспективі воно повинне мати чітку антикризову стратегію, яка представляє собою завчасно розроблений план досягнення і підтримування на прийнятному рівні АСП і запровадження спеціальних антикризових заходів у тих випадках, коли фактичний рівень негативного впливу кризогенних факторів перевищує поріг стійкості. Підприємство, яке має високий рівень АС, має значні шанси своєчасного попередження настання кризової ситуації та уникнення її несприятливих наслідків [6].

Особливо актуальним для підприємства стає його здатність повертатися в стан економічної рівноваги після дії негативних кризових впливів. Практикою господарювання доведено, що швидше і 3 меншими втратами відновлюють свій докризовий стан ті підприємства, які мають чітку антикризову стратегію. Основою вибору і розробки стратегії має стати об'єктивне оцінювання АСП, побудоване на принципах збалансованої системи показників. Це дозволить адекватно відображати траєкторію руху в досягненні стратегічних цілей, достовірно діагностувати зміни, що відбуваються 100 
на підприємстві, формувати антикризовий інструментарій, що відповідає типу АСП.

1. Джерелюк Ю. О. Оцінювання внутрішньої антикризової стійкості туристичного підприємства. Глобальні та національні проблеми економіки. 2018. Вип. 21. URL: http://global-national.in.ua/issue-21-2018 (дата звернення: 25.06.2020). 2. Каплан Роберт С., Нортон Дейвид П. Сбалансированная система показателей. От стратегии к действию / пер. с англ. 2-е изд., испр. и доп. М. : Олимп-Бизнес, 2004. 320 с. 3. Кизим М. О., Пилипенко А. А., Зінченко В. А. Збалансована система показників : монографія. Х. : ВД «ІНЖЕК», 2007. 192 с. 4. Костіна О. М. Система показників для оцінки антикризової стійкості промислового підприємства. URL: http://repository.hneu.edu.ua>bitstream (дата звернення: 25.06.2020). 5. Костриченко В. М., Ковальчук В. О. Оцінювання антикризової стійкості підприємства: методичні аспекти. Вчені записки Таврійського національного університету імені В.І. Вернадського. Сер. Економіка і управління. 2019. Том 30 (69). N 5. 4. 2. С. 57-63. 6. Костриченко В. М. Антикризова стійкість підприємства: оцінювання на засадах збалансованої системи показників. Економіка і управління підприємствами: теорія, методика, практика : колективна монографія / кол. авторів. Полтава : ПП «Астрая», 2020. 240 с. С. 209-214. 7. Коюда В. О., Костіна О. М. Напрями та складові оцінювання антикризової стійкості промислового підприємства. Теоретичні і практичні аспекти економіки та інтелектуальної власності. 2015. Вип. 2 (12). T. 2. С. 39-47. URL: http://nbuv.gov.ua/UJRN/Tpaeiv_2015_2(2)_8 (дата звернення: 25.06.2020). 8. Локтионов М., Зуб А. Теория и практика антикризисного управления. М. : Генезис, 2005. 576 с. 9. Бурштин України : офіційний сайт ДП. URL: http://amber-gem.com (дата звернення: 25.06.2020). 10. Пілецька С. Т. Методологія антикризового управління економічною стійкістю авіапідприємств : дис. ... д-ра екон. наук : 08.00.04. Київ, 2014. 791 с. 11. Рогова В. А. Концепция и этапы управления антикризисной устойчивостью организаций. Вестник ЮРГТУ (НПИ). 2012. № 1. С. 51-55. 12. Свобода Т. І. Теоретичні передумови формування антикризової стратегії торговельного підприємства. Економічна стратегія перспективи розвитку сфери торгівлі та послуг. 2009. Вип. 2. С. 322-329. URL: http://nbuv.gov.ua/UJRN/esprstp_2009_2_48 (дата звернення: 25.06.2020). 13. Урывская Л. В. Повышение антикризисной устойчивости сельскохозяйственных предприятий в системе государственного регулирования АПК : автореф. дис. ... канд. экон. наук : 08.00.05. М., 2010. 20 с. 14. Harrington J. The desirability function. Industrial Quality Control. 1965. No 21(10). P. 494-498. 15. Kostrychenko V., Kravtsiv M. Methodical imperatives in estimating of economic stability of the enterprise. International Journal of New Economics, Public Administration and Law. Varna-Świnoujście, 2018. № 1 (1). P. 101-111.

\section{REFERENCES:}

1. Dzhereliuk Yu. O. Otsiniuvannia vnutrishnoi antykryzovoi stiikosti turystychnoho pidpryiemstva. Hlobalni ta natsionalni problemy ekonomiky. 2018. Vyp. 21. URL: http://global-national.in.ua/issue-21-2018 (data zvernennia: 25.06.2020). 2. Kaplan Robert S., Norton Deivyd P. Sbalansyrovannaia systema pokazatelei. Ot stratehyy $k$ deistvyiu / per. s anhl. 2-e yzd., yspr. y dop. M. : Olymp-Byznes, 2004. 320 s. 3. Kyzym M. O., Pylypenko A. A., Zinchenko V. A. Zbalansovana systema pokaznykiv : 
monohrafiia. Kh. : VD «INZhEK», 2007. 192 s. 4. Kostina O. M. Systema pokaznykiv dlia otsinky antykryzovoi stiikosti promyslovoho pidpryiemstva. URL: http://repository.hneu.edu.ua>bitstream (data zvernennia: 25.06.2020). 5. Kostrychenko V. M., Kovalchuk V. O. Otsiniuvannia antykryzovoi stiikosti pidpryiemstva: metodychni aspekty. Vcheni zapysky Tavriiskoho natsionalnoho universytetu imeni V.I. Vernadskoho. Ser. Ekonomika i upravlinnia. 2019. Tom 30 (69). N 5. Ch. 2. S. 57-63. 6. Kostrychenko V. M. Antykryzova stiikist pidpryiemstva: otsiniuvannia na zasadakh zbalansovanoi systemy pokaznykiv. Ekonomika i upravlinnia pidpryiemstvamy: teoriia, metodyka, praktyka : kolektyvna monohrafiia / kol. avtoriv. Poltava : PP «Astraia», 2020. 240 s. S. 209-214. 7. Koiuda V. O., Kostina O. M. Napriamy ta skladovi otsiniuvannia antykryzovoi stiikosti promyslovoho pidpryiemstva. Teoretychni i praktychni aspekty ekonomiky ta intelektualnoi vlasnosti. 2015. Vyp. 2 (12). T. 2. S. 39-47. URL: http://nbuv.gov.ua/UJRN/Tpaeiv_2015_2(2)_8 (data zvernennia: 25.06.2020). 8. Loktyonov M., Zub A. Teoryia y praktyka antykryzysnoho upravlenyia. M. : Henezys, 2005. 576 s. 9. Burshtyn Ukrainy : ofitsiinyi sait DP. URL: http://amber-gem.com (data zvernennia: 25.06.2020). 10. Piletska S. T. Metodolohiia antykryzovoho upravlinnia ekonomichnoiu stiikistiu aviapidpryiemstv : dys. ... d-ra ekon. nauk : 08.00.04. Kyiv, 2014. 791 s. 11. Rogova V. A. Kontseptsiya i etapyi upravleniya antikrizisnoy ustoychivostyu organizatsiy. Vestnik YURGTU (NPI). 2012. № 1. C. 51-55. 12. Svoboda T. I. Teoretychni peredumovy formuvannia antykryzovoi stratehii torhovelnoho pidpryiemstva. Ekonomichna stratehiia i perspektyvy rozvytku sfery torhivli ta posluh. 2009. Vyp. 2. S. 322-329. URL: http://nbuv.gov.ua/UJRN/esprstp_2009_2_48 (data zvernennia: 25.06.2020). 13. Uryivskaya L. V. Povyishenie antikrizisnoy ustoychivosti selskohozyaystvennyih predpriyatiy $v$ sisteme gosudarstvennogo regulirovaniya APK : avtoref. dis. ... kand. ekon. nauk : 08.00.05. M., 2010. 20 s. 14. Harrington J. The desirability function. Industrial Quality Control. 1965. No 21(10). P. 494-498. 15. Kostrychenko V., Kravtsiv M. Methodical imperatives in estimating of economic stability of the enterprise. International Journal of New Economics, Public Administration and Law. VarnaŚwinoujście, 2018. № 1 (1). P. 101-111.

Kostrychenko V. M. [1; ORCID ID: 0000-0003-4210-6105], Candidate of Economics (Ph.D.), Associate Professor, Kovalchuk V. O. [1; ORCID ID: 0000-0002-9762-2513], Master

\section{JUSTIFICATION OF QUANTITATIVE AND QUALITATIVE ASSESSMENT OF ANTI-CRISIS STABILITY OF ENTERPRISE}

The enterprise, like any economic system, operates in conditions of permanent changes in the external economic environment and internal potential, which violate its equilibrium. For the company as a market player, its is vital to return to a state of economic equilibrium after the effects of negative crisis effects. The lack of timely response of the enterprise and proper management influence leads to the fact that the symptoms of a crisis 
situation can become a serious threat to its further functioning. These arguments prove the need for preventive anti-crisis management. That is why the issues of assessment and identification of anti-crisis stability of the enterprise become especially relevant.

The article reveals the essential characteristics of the anti-crisis stability of the enterprise. A critical analysis of methods for assessing the crisis resilience of the enterprise. An algorithm of comprehensive substatiation of parameters for assessing the anti-crisis stability of the enterprise on the basis of a balanced scorecard. In the context of four projections (finance, clients, internal business processes, training and development of staff), a system of functional components and corresponding indicators of anti-crisis stability of the enterprise are proposed. Using analytical procedures, a quantitative assessment of the level of anti-crisis stability of the enterprise by the integral indicator was made. In the process of qualitative evaluation, a map was developed to assess the crisis resistance of the enterprise, which allowed to identify its type and correspondence to the stage of the crisis process. Based on the results of calculations, a system of strategic goals and measures (initiatives) to increase the anti-crisis resilience of the enterprise is proposed. The projected estimation of change of anti-crisis stability of the investigated enterprise is carried out.

Keywords: anti-crisis stability; evaluation of crisis anti-crisis enterprise stability; balanced scorecard; integral indicator; anti-crisis stability level; anticrisis enterprise strategy.

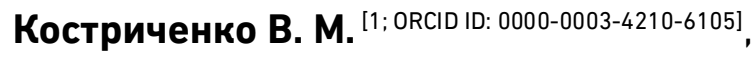
к.э.н., доцент,

Ковальчук В. А. ${ }^{[1 ; 0 R C I D ~ I D: ~ 0000-0002-9762-2513], ~}$ соискатель высшего образования второго (магистерского) уровня

${ }^{1}$ Национальный университет водного хозяйства и природопользования, г. Ровно

\section{ОБОСНОВАНИЕ КОЛИЧЕСТВЕННОГО И КАЧЕСТВЕННОГО ОЦЕНИВАНИЯ АНТИКРИЗИСНОЙ УСТОЙЧИВОСТИ ПРЕДПРИЯТИЯ}

Раскрыта сущностная характеристика антикризисной устойчивости предприятия. Проведен критический анализ методик оценивания антикризисной устойчивости предприятия. Разработан алгоритм комплексного обоснования параметров оценивания антикризисной устойчивости предприятия на принципах сбалансированной системы 
показателей. В разрезе четырех проекций (финансы, клиенты, внутренние бизнес-процессы, обучение и развитие персонала) предложена система функциональных составляющих и соответствующих показателей антикризисной устойчивости предприятия. Используя аналитико-оценочные процедуры, выполнено количественное и качественное оценивание уровня антикризисной устойчивости предприятия. На основании результатов расчетов предложена система стратегических целей и мероприятий (инициатив) по повышению антикризисной устойчивости предприятия. Произведено прогнозное оценивание изменения антикризисной устойчивости исследуемого предприятия.

Ключевые слова: антикризисная устойчивость; оценивание антикризисной устойчивости предприятия; сбалансированная система показателей; интегральный показатель; уровень антикризисной устойчивости; антикризисная стратегия предприятия. 